\title{
FROM AMBIVALENCE TO CERTAINTY: NORMS AND PRINCIPLES FOR THE STRUCTURAL INTERDICT IN SOCIO-ECONOMIC RIGHTS LITIGATION IN SOUTH AFRICA
}

\author{
CHRistopher MBAZIRA*
}

\begin{abstract}
The parsimonious approach of the Constitutional Court in using the structural interdict in socio-economic rights cases has both been critiqued and also contrasts with that of the High Courts. Moreover, the Court has neither given a principled basis for its rejection and use of the remedy nor laid down any norms and principles for determining when the remedy is appropriate. Starting from these bases, this article highlights norms and principles which could guide the courts in determining when the structural interdict is appropriate, and its modalities. Drawing upon Amersican jurisprudence, the article proposes norms and principles including utilisation of the structural interdict in a graduated manner as a remedy of last resort; participation of all stakeholders; judicial impartiality and independence; reasoned decision making; remediation which enforces the substantive norms; and flexibility.
\end{abstract}

\section{INTRODUCTION}

The South African Constitutional Court has been admonished for its reluctance to use the structural interdict as a remedy in socio-economic rights cases. The Court's reluctance is considered by some critiques to be one of the reasons why adjudication of socio-economic rights has not made a very

* LLB, LLM, PhD; lecturer in the Department of Public \& Comparative Law, Makerere University and researcher fellow Community Law Centre, University of the Western Cape. This paper is extracted from one of the chapters in my doctoral thesis titled: 'Enforcing the Economic, Social and Cultural Rights in the South African Constitution as Justiciable Individual Rights: The Role of Judicial Remedies', I am grateful to my promoter, Professor Pierre de Vos, for his invaluable comments and to Professor Israel Leeman and my former colleagues Dr Lilian Chenwi, Sibonile Khoza and Christopher Heleba for their comments and insights. The comments of an anonymous reviewer are also acknowledged.

Author's current address:

Department of Public \& Comparative Law

Faculty of Law

Makerere University

P.O. Box 7062 Kampala — Uganda

Tel: (+256 392) 967390

<bazzira@yahoo.co.uk>; <cmbazira@law.mak.ac.uk> 
big impact in the lives of the poor. ${ }^{1}$ The reluctance is also viewed as one of the reasons for failure by the executive to enforce the Constitutional Court's orders. This is in addition to the failure of the Court to monitor the enforcement of its orders. ${ }^{2}$ The approach of the Constitutional Court in using the structural interdict in socio-economic rights cases contrasts with that of the High Courts. Unlike the Constitutional Court, the High Courts have readily availed themselves of this form of relief to enforce socio-economic rights. ${ }^{3}$ The approach of the Constitutional Court also differs between civil and political rights litigation and socio-economic rights litigation. The Constitutional Court has readily issued the structural interdict in litigation touching on the civil and political rights in the Constitution. ${ }^{4}$ The Court has acknowledged the availability of this form of relief as an appropriate, just and equitable remedy in socio-economic rights litigation. In spite of this, the Court has declined to use the relief on the basis that the executive has always respected its orders; this is so even in those cases where there is evidence to the contrary. ${ }^{5}$

What is more apparent, however, is that the Constitutional Court has been ambivalent in determining the circumstances under which the structural interdict would be considered an appropriate, just and equitable remedy. The Court has neither given a principled basis for its rejection and use of the remedy nor laid down any norms and principles for determining when the remedy is appropriate. This could be one of the reasons that the Court's approach has received more negative criticism than praise. ${ }^{6}$ In spite of this,

1 M Swart 'Left out in the Cold? Crafting Constitutional Remedies for the Poorest of the Poor' (2005) 21 SAJHR 215, 228. See also D Bilchitz 'Giving Socio-economic Rights Teeth: The Minimum Core and its Importance' (2002) 118 SALJ 484, 501.

2 DM Davis 'Socio-economic Rights in South Africa: The Record of the Constitutional Court after Ten Years' (2004) 5 ESR Review 3, 5. See also DM Davis 'Adjudicating the Socio-economic Rights in the South African Constitution: Towards "Deference Lite" (2006) 22 SAJHR 300, 312. Davis argues that a refusal to grant a structural interdict has prevented the Constitutional Court from monitoring the efficacy of any order granted and hence being compelled to engage in the very mechanisms of policy implementation.

3 See Grootboom v Oostenberg Municipality and Others 2000 (3) BCLR 277 (C) (Grootboom Oostenberg case); $S v$ Zuba and 23 similar cases 2004 (4) BCLR 410 (E) (Zuba case); City of Cape Town v Rudolph and Others 2003 (11) BCLR 1236 (C) (Rudolph case), Centre for Child Law and Others v MEC for Education and Others, Case No. 19559/06 [Unreported] (the Luckhoff case), High Courts Transvaal Provincial Division; and EN and Others $v$ Government of RSA and Others 2007 (1) BCLR 84 (D) (Westville case).

4 See August and Another v Electoral Commission 1999 (4) BCLR 363 (CC) (August case); and Sibiya and Others v DPP, Johannesburg High Courts and Others, 2006 (2) BCLR 293 (CC) (Sibiya case).

5 See, for instance, Minister of Health and Others $v$ Treatment Action Campaign 2002 (5) SA 721 (CC) (TAC case), where the Minister of Health, Manto Tshabalala-Msimang indicated openly, in the public arena, that government would not abide by any orders made against it by the Court. Rationalising the decisions to appeal the High Court judgment, the Minister reasoned that if this judgment were allowed to stand, it would create a precedent that could be used by a wide variety of interest groups wishing to exercise quite specific influences on government policy in the area of socio-economic rights, and could open the way for a spate of court applications and 'policy judgments'. See 'Government, not Courts, must Decide HIV/AIDS and Other Social Policy' Sunday Times 30 December 2001.

6 See note 1 above. 
with a few exceptions, ${ }^{7}$ the critics have not come to the aid of the Court by comprehensively defining norms and principles that could govern this type of remedy. The critics have been motivated, arguably, mainly by frustration that socio-economic rights litigation has thus far not resulted in rapid socioeconomic transformation, as was eagerly anticipated at the adoption of the Constitution. There is also a general feeling that victories at the conclusion of socio-economic rights cases have been hollow, as the lives of successful litigants have not improved dramatically.

It is not my intention to undermine the relevance and basis of the frustration above. The objective of this paper is to highlight norms and principles which could guide the courts in determining when the structural interdict is appropriate, and its modalities. The norms and principles suggested here therefore provide a principled basis for either rejecting or using the structural interdict. They will also provide a foundation upon which to critique the courts' approach as regards the use of the structural interdict in future. These norms and principles should, by their nature, be capable of application in a number of contexts. This is because, rather than attempt to construct a rigid rule, courts should focus on the broad principles that guide the exercise of remedial discretion and ones that could be used in a variety of contexts. ${ }^{9}$ The norms and principles I propose include: utilisation of the structural interdict in a graduated manner as a remedy of last resort; participation of all stakeholders; judicial impartiality and independence; reasoned decision making; remediation which enforces the substantive norms; ${ }^{10}$ and flexibility.

While some principles could be deduced from the approaches of the High Courts and Constitutional Court, these are not comprehensive and need to be enhanced and elaborated upon. I do not purport the principles I have enunciated here to be exclusive; more principles will emerge from scholarly and judicial discourse as jurisprudence on the subject grows. The paper begins by understanding the rather novel remedy.

This paper places heavy reliance on United States literature and jurisprudence in formulating the norms and principles deemed relevant to South Africa. The reason for this is obvious; the United States judiciary is credited with being the initiator of this form of relief. Yet the controversial nature of the structural interdict, as a constitutional remedy, has generated a large volume of scholarly work. ${ }^{11}$

7 See K Roach and G Budlender 'Mandatory Relief and Supervisory Jurisdiction: When is it Appropriate, Just and Equitable?' (2005) 122 SALJ 325, 351.

8 See Swart (note 1 above) and Davis (note 2 above).

9 Roach \& Budlender (note 7 above) 333.

10 See S Sturm ‘A Normative Theory of Public Law Remedies' (1991) 79 GLJ 1355.

11 See, for instance, Sturm (as above); D Horowitz 'Decreeing Organizational Change: Judicial Supervision of Public Institutions' (1983) Duke LJ 1265; M Schlanger 'Beyond the Hero Judge. Institutional Reform Litigation as Litigation' (1999) 97 Michigan LR 1994; Chayes, supra (note 13); F Sabel and H Simon 'Destabilization Rights: How Public Law Litigation Succeeds' (2004) 117 Harv L R 1015; S Diver 'The Judge as Political Powerbroker: Superintending Structural Change in Public Institutions (1979) 65 Vir L R 43; and Eisenberg \& Yeazell (note 24 below). 


\section{Anatomy of the Structural Interdict}

In the South African context, the structural interdict could be described as a recent development 'created by a new and transformative constitutional order." The structural interdict is a complicated form of interdict, which involves the continued participation of the court in the implementation of its orders. Once the court has handed down its judgment and made an order, it does not relinquish the case. Instead, it monitors the implementation of its orders and may require the parties to report back to it in this regard..$^{13}$ The structural interdict as a remedy in constitutional litigation is traced back to the United States school desegregation cases. The leading case in this respect is Brown v Board of Education. ${ }^{14}$ This case was propelled by the need to realise transformation of the dual school system, based on race, into a unitary and non-racial school system. It required a great deal of organisational reform to transform the entrenched racial segregation, which had survived for hundreds of years. The courts were required to transform this entrenched status quo and to reconstruct the social reality in a radical manner. What was required included establishing new procedures for student assignments, new criteria for construction of schools, revision of transport routes, re-assignment of facilities, curricular modifications, reallocation of resources, and above all, establishing equity in the school system. The question is whether all these objectives would have been achieved through the conventional one-stance traditional litigation and remedial procedures. The answer is a definite no; it required protracted and unusual methods of litigation and remediation; hence the resort to the structural interdict to ensure that the obstinate school and local authorities implemented the desired reforms.

The functions of the structural interdict are various and determined by the circumstances and demands of each case. Unlike other forms of interdicts or remedies, such as damages, the purpose of a structural interdict is not deterrence or compensation as such. In broad terms, its purpose is the elimination of systemic violations existing especially in institutional or organisational settings. ${ }^{15}$ Rather than compensate for past wrongs, it seeks to adjust future behaviour, and is deliberately fashioned rather than logically deduced from the nature of the legal harm suffered. Its most prominent feature is the creation of a complex ongoing regime of performance, and it is not a one-shot and one-way approach to providing judicial remedies. ${ }^{16}$ Its ongoing nature is facilitated by the court's retention of jurisdiction, and sometimes by the court's active participation in the implementation of the decree. By using the structural interdict, the courts disregard the traditional

12 Roach \& Budlender (note 7 above) 328.

13 For a discussion of the features of this form of relief, see A Chayes 'The Role of the Judge in Public Law Litigation' (1979) 89 Harv LR 1281. See also W Trengove 'Judicial Remedies for Violations of Socio-economic Rights' (1999) 1 ESR Review 8.

14349 US 294 (Brown case).

15 See S Liebenberg 'The Value of Human Dignity in Interpreting Socio-economic Rights' (2005) 21 SAJHR 1, 30.

16 Chayes (note 13 above) 1298. 
functus officio doctrine. This doctrine requires that once a court has made a final determination of a matter, its jurisdiction over the case ceases, and the case is closed. ${ }^{17}$

The structural interdict is a response to the inadequacy of traditional remedies in responding to systemic violations of a complex organisational nature. ${ }^{18}$ The traditional remedies, such as damages and ordinary interdicts, may not effectively eliminate systemic violations. In a setting of systemic violations, what would be most appropriate are those remedies which aim at achieving structural reforms by tackling the systemic problems at their root rather than by redressing their impact. This may require development of ongoing measures designed to eliminate the identified mischief, ${ }^{19}$ and to promote participation of not only the parties but also third parties in the remedy selection process. Dealing with systemic violations in institutional settings also requires a continued establishment of facts and the continual interplay between such facts and the legal consequences. ${ }^{20}$ This is important because in such cases, the problems could have their roots in the structural characteristics of the institution itself. ${ }^{21}$ Facts which enhance the court's understanding of the nature of the institution, therefore, become relevant at all stages of the case. ${ }^{22}$ The cases may also require frequent redetermination of liability and reformulation of relief. ${ }^{23}$

It is because of these factors that the structural interdict has become a preferred remedy in what has been described as structural or institutional suits. $^{24}$ These suits challenge large scale government deficiencies, sometimes arising out of organisational or administrative failure. The causes of the failure are various: failure to use (or misuse of) discretion; negligence; failure to comprehend the law; administrative red tape; and deliberate disregard of rights. Usually these suits are preceded by political pressure and instituted only when this is unsuccessful. Even when they are filed, however, political pressure may continue to be exerted on the government. ${ }^{25}$ The suits are usually multi-partied, with large numbers of plaintiffs, who may act in a representative capacity for known and unknown victims. The suits could also have amici

17 For a detailed discussion of the functus officio doctrine see D Pretorius 'The Origins of the Functus Officio Doctrine with Specific Reference to its Application in Administrative Law' (2005) 122 SALJ 832. See also Special Project 'The Remedial Process in Institutional Reform Litigation' (1978) Colum LR 784, 816.

18 Sturm (note 10 above) 1357.

19 Chayes (note 13 above) 1297. See also Special Project (note 17 above) 812.

20 Chayes ibid.

21 Note 'Implementation Problems of Institutional Reform Litigation' (1998) 91 Harv LR 428, 433.

22 It has been submitted that understanding the institution will permit the policy maker, whether administrative or judicial, to anticipate obstacles to implementation and develop strategies of surmounting the obstacles. Ibid 435.

23 Special Project (note 17 above) 790. In fact, the Special Project has described the resulting decree as resembling a legislative or executive act.

24 See W Fletcher 'The Discretionary Constitution: Institutional Remedies and Judicial Legitimacy' (1982) Yale LJ 635, 637; T Eisenberg \& Yeazell (note 11 above).

25 Fletcher (as above). 
and interveners, and may be instituted against a multitude of government departments and institutions.

Courts have adopted different models of the structural interdict, not only in different cases but at different levels of the same case. The most commonlyused models include: the bargaining model; the legislative/administrative hearing model; the expert remedial formulation model; the report back to court model; and the consensual remedial formulation model. ${ }^{26}$

\section{(a) Bargaining model}

The bargaining model involves making remedial decisions through negotiation by the parties involved in the case. The biggest advantage of this model is that it produces a remedy that is acceptable to all the parties, thereby easing implementation. ${ }^{27}$ The negotiation process could also bring to the fore facts and issues which may have been ignored by the court, yet are relevant to having an effective remedy. Such facts and issues will emerge from the perspectives of all the parties. ${ }^{28}$

\section{(b) Legislative/administrative hearing model}

The legislative/administrative hearing model resembles a legislative committee process providing for public hearings and direct informal participation by interested parties. ${ }^{29}$ This model allows persons not originally party to the litigation, but who may be interested in the case, to participate in the formulation of the remedy. It is an effective model in responding to polycentric interests which may be implicated in the case. ${ }^{30}$ The problem of polycentricity in adjudication is deduced from the writings of Lon Fuller. ${ }^{31}$ Fuller argues that certain tasks are unsuited for judicial adjudication because any decisions on them will have multiple repercussions which may be difficult for the decision maker to comprehend. He identifies socio-economic rights as such matters, and discourages their adjudication through judicial means. ${ }^{32}$ In spite of this, the court may use the legislative/administrative model to appreciate all the interest in so called polycentric socio-economic rights cases.

28 See the United States case of Liddle v Board of Education of the City of St. Louis 491 F. Supp. 351 (E.D.Mo.1980).

29 See Sturm (note 10 above) 1370.

30 An example of a case where this model was used is the US case of Pennsylvania Association for Retarded Children v Pennsylvania 334 F.Supp. 1257 (E D. Pa. 1971) (PARC case).

31 L Fuller 'The Forms and Limits of Adjudication' (1978) 92 Harv LR 353.

32 I have critiqued Fuller's ideas in this regard and applied these to the adjudication of socio-economic rights. See C Mbazira 'Confronting the Problem of Polycentricity in Enforcing the Socio-economic Rights in the South African Constitution' (2008) 23 SAPR/PL 30. 


\section{(c) Expert remedial formulation model}

The expert remedial formulation model involves the appointment of either an individual expert or a panel of experts with a mandate to develop a remedial plan. Sometimes these experts are designated as court officials and have judicial powers. The court-appointed experts in structural litigation differ from those in other forms of litigation. Experts in other forms of litigation are always restricted to fact-finding mandates. By contrast, the experts in structural litigation are usually mandated to design and propose a remedial plan. ${ }^{33}$ The expert could even be designated as an administrator with a mandate to take over and manage the institution under scrutiny for the purpose of effecting reforms. The expert model is particularly relevant in cases where specialised and technical skill is required to formulate an appropriate remedy; for instance, where there is a need to appreciate some social information facts before formulating the order. ${ }^{34}$ The court may not have the expertise and skill to ascertain the social facts. This does not mean, however, that the parties are left out of the remedy-finding process. In spite of their skills, the experts may be obliged to consult with the parties in formulating the remedial plans. ${ }^{35}$ This, like the legislative hearing model, is intended to ensure that polycentric interests are considered and that the remedy is acceptable not only to the parties but also to other stakeholders who may play a role in its implementation. ${ }^{36}$

\section{(d) Report back to court model}

The report back to court model is the most commonly-used model and is implemented by requiring the defendant to report back to the court with a plan on how he or she intends to remedy the violation. Usually a fixed date is set for the filing of the plan, and the other party is given an opportunity to comment on the plan. It is only when the court is satisfied with the plan that it will concretise it as part of its final order.

The report back model has a number of advantages. First, it allows the court to defer to the defendant (often the government) on the most effective way of eliminating the violation. This promotes the doctrine of separation of powers and shields the court from accusations that it has usurped functions reserved for the other organs of state. The model also enables the court to harness the expertise that may be in the hands of the defendant. Where government is the defendant, the court could harness the usually rich expertise at the disposal of the state bureaucracy. Second, it allows for a self-imposed remedy from the defendant, which makes implementation of the remedy much simpler. It is highly unlikely that the defendant will propose a plan that he or she cannot carry out. In the case of government, such remedy will be calculated very

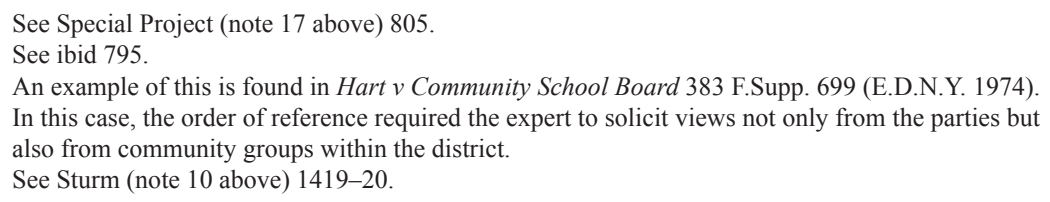


meticulously to cater for government's budgetary and related needs. However, the process may not be left entirely to the defendant, as both the court and the opposite party are afforded an opportunity to scrutinise the plan. In fact, the court may reject the plan if it is considered inadequate.

\section{(e) Consensual remedial formulation model}

The consensual remedial formulation model also tries to secure the consensus of the parties and third parties in the formulation of the remedy, and brings the same advantages as the bargaining model. ${ }^{37}$ This model allows parties to exchange views and raise contests in a less formal manner. It also fosters a good working relationship between the parties, and participation may be open to a variety of stakeholders. It is, however, important that the process be opened up to as many participants as possible. This is because the exclusion of persons who, although not parties to the suit, may be affected by its outcome, could hamper effective implementation of the resulting court order, as such person may put up opposition to it. ${ }^{38}$ At the same time, the process should not be opened unnecessarily to such an extent that reaching agreements becomes impossible because of the wide range of interests. The process should be directed by a third party able to co-ordinate and ensure the participation of all stakeholders.

The consensual remedial formulation model is in many respects similar to the bargaining model. The difference is that the consensual formulation model is less formalised and is readily opened to third party participants. The consensual public dispute resolution usually requires the assistance of a third party who acts as the keeper of the process and assumes responsibility for convening the deliberations, assisting groups in choosing spokespersons, helping to establish ground rules and an agenda, and identifying and obtaining expert assistance. ${ }^{39}$ It is important to note, though, that, just as with the bargaining model, the consensual model will work only where the parties are willing to compromise and have an interest in resolving a dispute. This could be because of a shared history or commitment to a shared cause. The model would not work well where the parties hold intractable and irreconcilable views that leave no room for compromise.

\section{The SOUTh African Approach}

\section{(a) The approach of the High Courts}

The High Courts have rejected the view that a declaratory order would be the only sufficient remedy for the government to implement orders from the

37 An example of this is in United States v Michigan 471 F.Supp. 192 (W.D. Mich. 1979), where a third party was appointed to assist the parties to come to an agreement on the allocation of fishing waters between tribes.

38 See M Schwarzschild 'Public Law by Private Bargain: Title VII Consent Decrees and the Fairness of Negotiated Institutional Reform' (1984) 5 Duk LJ pp 887-935.

39 Sturm (note 10) 1423. 
courts. According to the Court, a declaratory order without injunctive relief lacks practical content. ${ }^{40}$ Most importantly, however, the High Courts have resorted to the structural interdict because of its importance both to the applicants and the government. The relief is useful in cases where there is insufficient information before the court to determine the most appropriate relief that would redress the violation. The retention of jurisdiction allows the Court to acquire additional evidence relevant for defining the remedy without having to bother the parties with filing new papers when more information emerges. It should also be noted that it would be fair to the respondent government, which may need more time to come up with solutions. In one case the Court has held that:

In fairness to the respondents, who now know where their duty lies, they should be given an opportunity of proposing a practical solution. In fairness to the applicants, now that they know where their rights lie, respondents should be directed to make such proposals within a reasonable time. The applicants should furthermore have the opportunity of commenting on the proposal, and the respondents should be allowed to respond to such comment. ${ }^{41}$

The High Courts have also underlined the structural interdict as an appropriate response to systemic violations. It has been observed by one court that other remedies, 'such as declarator, the prohibitory interdict, mandamus, and awards of damages', are inappropriate to remedy 'systemic failures or the inadequate compliance with constitutional obligations, particularly when one is dealing with ... rights of a programmatic nature'. ${ }^{42}$

Additionally, the High Courts have been motivated to grant structural interdicts by the need to protect and promote the doctrine of separation of powers. The structural interdict has enabled the Court to give latitude to the executive branch of government by deferring to it on the most appropriate solutions to address unconstitutional conditions. In this respect, '[t]he structural injunction is not intended to substitute the judiciary for the administration, but to relieve the judge from framing relief in a way that would constitute democracy by judicial decree,. ${ }^{43}$ This, as seen above, is manifested in what the Court has described as the opportunity given to the respondent to propose a practical solution. According to Budlender, 'structural interdicts can be deeply democratising. They create spaces for dialogue between the court, the government and civil society actors. In this way, they strengthen and deepen accountability and participation — the key elements of democracy, ${ }^{44}$ Rather than violate the doctrine of separation of powers, the High Courts, therefore, view the structural interdict as a means of preserving the doctrine. The latitude given to the government to fashion the remedy indicates that the High Courts are not prepared to assume functions that are preserved for the execu-

44 G Budlender 'The Role of the Courts in Achieving the Transformative Potential of Socio-economic Rights' (2007) 8 ESR Review 9, 11. 
tive organ of the state. The executive branch is, therefore, required to execute self-imposed rather than judicial imposed remedies.

It appears, however, that the main reason the High Courts have resorted to the structural interdict is to counter government recalcitrance. ${ }^{45}$ This is in addition to 'the dilatory and lackadaisical approach taken' by the state in some cases. ${ }^{46}$ The recent Westville case ${ }^{47}$ is evidence of this. The degree of recalcitrance exhibited by the government in this case makes it worthwhile discussing the case in detail. The AIDS Law Project (ALP) together with the Treatment Action Campaign (TAC) commenced the case for $15 \mathrm{HIV} /$ AIDS positive prisoners from the Westville correction facility in KwazuluNatal. The applicants sought orders to compel the government to remove all obstacles preventing the 15 and other similarly-placed prisoners from accessing anti-retroviral treatment (ARV treatment). They also sought an order that the government provide the 15 and other similarly-situated prisoners with ARV treatment, in accordance with the existing government Operational Plan for Comprehensive HIV and AIDS Care, Management and Treatment (Operational Plan). ${ }^{48}$ The applicants argued that the Operational Plan had not been implemented with reasonable speed and urgency.

The Court found implementation of the Operational Plan to be unreasonable and inflexible, which had result in a disregard of the needs of prisoners. The respondents were ordered to remove the obstacles which prevented prisoners from accessing ARVs under the Operational Plan. ${ }^{49}$ The Court found the respondents to have acted with dilatoriness and a lack of commitment on their part. ${ }^{50}$ Even when some agreement had been reached between the parties outside court, this had not been honoured by the respondents, who instead chose to engage in adversarial litigation. This behaviour motivated the judge to retain jurisdiction and to order that the respondents file a plan within two weeks on how they intended to implement the court order. ${ }^{51}$

Rather than implement the court order in good faith, the respondents instead pursued a technicality-based appeal arising from the judge's rejection of a recusal request, on the ground that one of the counsel for the applicants was his daughter. The respondents also failed to file the plan on the due date and instead sought to set aside an interim order made for the implementation of the orders of the Court pending the appeal. The application to stay the order came before Nicholson $\mathrm{J}^{52}$ who found that irreparable harm would be suffered by the prisoners if the interim order were set aside. The harm that the prisoners would suffer was not comparable to the inconvenience likely

See Rudolph case (note 3 above).

Luckhoff case (note 3 above) pages 7 to 9 of the unreported judgment.

Note 3 above.

Available at <http://www.info.gov.za/otherdocs/2003/aidsoperationalplan.pdf $>$.

See para 35 .

50 See para 24. The judge found 'a singular lack of commitment to appreciate the seriousness and urgency of the situation'.

51 See paras $32-33$.

52 Also recorded as EN and Others $v$ Government of RSA and Others Case No. 4576/06 [Unreported]. 
to be suffered by the state. ${ }^{53}$ Nicholson castigated the state for creating a constitutional crisis: 'If the government ... has given such an instruction [to disobey the Court order] then we face a grave constitutional crisis involving a threat to the doctrine of separation of powers. Should that continue the members of the judiciary will have to consider whether their oath of office requires them to continue on the bench'. ${ }^{54}$

This judgment demonstrates how government recalcitrance can break down dialogue between the courts and the executive, and the struggles by the judiciary to restore this dialogue. The judgment also shows the minimal appreciation, if not misunderstanding, on the part of the executive of their constitutional obligations, and the role of the judiciary in reasserting these obligations through means such as the structural interdict. Rather than lead to a breakdown of the relationship between the judiciary and the executive, the structural interdict should be viewed as promoting a dynamic dialogue between these two branches. This dialogue is on the intricacies of implementing court orders and actualising constitutional rights. ${ }^{55}$ It is clear from this case that, rather than be deferential, in some cases where there is evidence of recalcitrance from the start, use of a structural interdict as a remedy of first resort may be justified. The South African government has in the past exhibited inconsistence and incoherence towards the HIV/AIDS epidemic. ${ }^{56}$ This leaves the courts with no option but to demand, on those occasions when cases are filed, concrete plans detailing the intended response to the problem. The persistence of the court in this case forced the government to give in and file a plan as earlier directed. ${ }^{57}$

It should be noted, however, that although the High Courts have readily availed themselves of the structural interdict and used it consistently, they have not devised clear principles that could determine when such remedy is appropriate. The courts have deemed the remedy appropriate whenever there is recalcitrance on the part of government. In spite of this, the judgments do not detail all the relevant principles needed to determine appropriateness and use of this form of relief. In addition, there should also be principles on how the remedy should be applied. The High Courts have, for instance, not determined the level of recalcitrance that would justify use of the remedy, let alone the causes of such recalcitrance. It is this lack of clear principles in respect of application of the structural interdict that has motivated me to craft a set of norms and principles applicable to this remedy.

55 M Pieterse 'Coming to Terms with Judicial Enforcement of Socio-economic Rights' (2004) 20 SAJHR 383, 414.

56 See 'Aids Criticism: Manto Hits Back' Mail \& Guardian online 11 September 2006. See also D Bilchitz 'Towards a Reasonable Approach to the Minimum Core: Laying the Foundations for Future Socio-economic Rights Jurisprudence' (2003) 19 SAJHR 1, 24.

57 See G Stolley 'Prisons Dept Reveals Plan for Aids Drugs' Mail \& Guardian online 11 September 2006. 
One should, however, underline some of the important principles which may be deduced from the High Courts' approach. These principles, although not exhaustive, are relevant in designing a more comprehensive set of norms and principles, as is done later in this article. First, the High Courts have made it clear that the court should retain jurisdiction where the information before the court is not enough for the purpose of determining the most appropriate relief. In such case, the parties should be saved the trouble of having to institute fresh litigation when new evidence or facts come to the fore. Second, the structural interdict should be used as a means of showing respect to the other branches of the state in responding to the declared violation. This is especially so where the court is not clear on the most appropriate way of remedying the violation. The executive and legislative branches should be given the latitude to devise what they consider the best means of remedying the violation. The means should, however, be subject to scrutiny by the court and the opposite party. Lastly, the structural interdict should be resorted to in the face of government recalcitrance. Where there is evidence that the government will not comply, in good faith, with the orders of the court, the structural interdict is appropriate. $^{58}$

\section{(b) The approach of the Constitutional Court}

The Constitutional Court has emphatically asserted its powers to grant all forms of relief including a structural interdict, and to exercise supervisory jurisdiction if need be. ${ }^{59}$ According to the Court, " $[\mathrm{t}]$ he power to grant mandatory relief includes the power where it is appropriate to exercise some form of supervisory jurisdiction to ensure that the order is implemented ${ }^{60}{ }^{60}$ The Court also views the structural interdict as a practical remedy, which would eradicate conduct giving rise to violation of constitutional rights. ${ }^{61}$ Like the High Courts, the Constitutional Court has deemed the structural interdict appropriate in those cases where the information before the Court is inadequate for the purposes of making a final order. ${ }^{62}$ This is in addition to the lack of expertise on the part of the Court to make appropriate arrangements for the eradication of the violation. ${ }^{63}$ The Court has thus allowed those with information and expertise the time to devise and submit to the Court plans on how they intend to eradicate the violation. ${ }^{64}$

Again, like the High Courts, the Constitutional Court has used the structural interdict in those cases where there is evidence of lackadaisical conduct on the part of the government. In the Sibiya case, ${ }^{65}$ for instance, the Court was concerned that the process of commuting death sentences following the

See also Roach \& Budlender (note 7 above).

See Pretoria City Council v Walker 1998 (2) SA 363 (CC) (Pretoria Council case), para 96.

TAC case (note 5 above), para 104.

See Pretoria Council case (note 56 above), para 96.

August case (note 4 above), para 39.

Ibid.

64 Ibid.

65 Note 4 above. 
Makwanyane case ${ }^{66}$ had taken far too long. ${ }^{67}$ The Court, therefore, deemed the structural interdict appropriate in the circumstances. Government was ordered to take immediate steps to ensure that all sentences of death imposed before 5 June 1995 were set aside and replaced by an appropriate alternative sentence. The government was also required to report to the Court not later than 15 August 2005 on all the steps taken to comply with the order above. Instead of filing the report before 15 August 2005, the government on 12 August 2005 filed an application for extension of the time for filing the report. ${ }^{68}$ The Constitutional Court allowed the application and extended the time to 15 September 2005. Thereafter, however, even with the defects detected in the report filed on 15 September 2005, the Court granted the government still more time to rectify the defects and file another report by 7 November 2005. But the November report was also lacking, to the extent that the sentences of some 28 people had not been substituted. A further extension was given to the government to file an additional report by 15 February 2006. Yet the February report still had names of persons whose sentences had not been substituted, which attracted a further extension to 15 May 2006. The May report was also not fully compliant; the sentence of one person had not been substituted. This led to a further extension of up to 1 September 2006. But before 1 September 2006 the government reported, to the satisfaction of the Court, that all sentences had been substituted.

This case is important in a number of respects. It is evidence of the fact that where the government fails to act in a timely manner in the face of a structural interdict, the Court is prepared to continue to engage the government until full compliance is obtained. This is because in some cases it is only after several rounds of engagement that government may fully comply. ${ }^{69}$ The Court and interested parties must, therefore, be patient and be prepared to engage the government on more than one occasion.

The case is also important because, at the end, the Court made some observations which could inform the procedures that ought to be followed when courts deem supervisory jurisdiction appropriate. These procedures are also relevant in developing a comprehensive set of norms and principles for the structural interdict. The Court observed that the supervisory process in the case had shown the following:

- Successful supervision requires that detailed information be placed at the disposal of a court; structural interdict on the basis of the attitude of denial expressed by government by deliberately failing to recognise the plight of the respondents and applying the principles in the Grootboom case, to the effect that those in desperate need should not be ignored. There were several rounds of engagement until compliance was achieved. The municipality was made to return to court three times.
} 
- Supervision entails a careful analysis and evaluation of the details provided;

- Supervision cannot succeed without the full co-operation of others in the process; and

- Courts should be flexible in the supervisory process. ${ }^{70}$

As already mentioned, the willingness on the part of the Constitutional Court to exercise supervisory jurisdiction differs between civil and political rights cases and socio-economic rights cases. ${ }^{71}$ The Constitutional Court has been reluctant to use this form of relief to enforce socio-economic rights. This reluctance has been inspired by what the Court considers to be a need to maintain the divide between itself and the other branches of the state as dictated by the doctrine of separation of powers. For the sake of maintaining the boundaries of separation of powers, the Constitutional Court has conceptualised the structural interdict as a remedy that should be used as a matter of last resort when all else fails. The Court has also been sceptical about the structural interdict in socio-economic rights cases because of its reluctance to be involved in protracted litigation in the implementation of its orders. According to one commentator, the Constitutional Court would like to be 'a "one-stop shop" in resolving these cases - they do not want to look at a case again once they have decided on it'. ${ }^{72}$

According to Davis, '[t]he less the burden on the Constitutional Court to exercise supervision over the executive, the more comfortable it feels ${ }^{73}$ There is an indication that the remedy has been reserved for those cases where there is recalcitrance on the part of government to implement the directions of the Court. However, the Constitutional Court has been ambivalent in determining the existence of such recalcitrance in socio-economic rights cases. According to the former Chief Justice, Arthur Chaskalson:

If there is not the political will, supervisory orders are not likely to be effective and may drag courts into long drawn battles that could more appropriately and more effectively be fought on the political terrain. Those battles should be fought first, and if successful, the results are likely to be more effective than attempts to secure compliance through court supervision. A structural interdict may be necessary in a particular case to ensure that relief granted is effective relief; for instance if there is deliberate failure to heed a declaratory order or other relief granted by a court. But it should be a last resort and not a routine response to claims for the enforcement of socio-economic rights. ${ }^{74}$ [Emphasis mine]

72 S Khoza 'The Importance of a Dialogue on Strategies to Promote Socio-economic Rights in South Africa' (2006) 7 ESR Review 6, 9. However, unlike the approach of the minority in the Canadian case of Doucet-Boudreau v Nova Scotia [2003] 3 S.C.R. 3 (Doucet-Boudreau case), the Constitutional Court has not radically rejected the structural interdict on the basis of such principles as functus officio. Instead, it has left its use open as a remedy that could be granted in 'deserving cases'.

73 Davis (note 2 above) 304.

74 Former Chief Justice Arthur Chaskalson's speech 'Implementing Socio-economic Rights: The Role of the Courts', delivered as guest speaker at the 3rd Dullah Omar Memorial Lecture, organised by the Community Law Centre and the Faculty of Law at the University of the Western Cape 13 June 2006 at p 31 . 
This appears to be the basis upon which the Constitutional Court rejected and set aside structural interdicts granted by the High Courts in the Grootboom and TAC cases. ${ }^{75}$ The Court also declined to comment on the structural interdict that had been granted by the High Court in Modderklip Boerdery (Pty) Ltd and Others $v$ President of RSA and Another (Modderklip case)..$^{76}$

The Constitutional Court's reluctance to use the structural interdict in socio-economic rights cases has generated condemnation and castigation of the Court as undermining the socio-economic rights in the Constitution. ${ }^{77}$ This is because it has left court orders powerless in the face of government recalcitrance. According to Davis:

... the Court's ... refusal to grant structural relief that would empower courts to supervise the implementation of their own orders has produced unfortunate results. Litigants have won cases and government has done little to produce the tangible benefits that these litigants were entitled to expect from their success. The Court, in effect, has surrendered its powers to sanction government inertia and, as a direct result, litigants have not obtained the shelter or drugs that even a cursory reading of the judgments promised. ${ }^{78}$

It has also been submitted that exercising supervisory jurisdiction in socioeconomic rights cases would have saved the time and expenses that parties would have to endure to challenge state action through filing fresh suits. ${ }^{79}$

The Constitutional Court's reluctance to exercise supervisory jurisdiction in socio-economic rights cases, just like its rejection of the minimum core obligations approach, appears to be rooted in the need to preserve the boundaries of the separation of powers. ${ }^{80}$ The Court has been particularly cautious to defer to the executive branch as regards issues of budgetary allocation. In those cases where the Court has risen to the occasion to interpret the rights, it has also been keen to push the cases out of its doors as soon as possible. This would not be possible if jurisdiction were retained, as the Court would have to engage in budgetary issues in the course of its supervision. This could be one of the factors which explain the ambivalent approach of the Constitutional Court, as well as its differentiated approach as regards civil and political rights litigation when compared to socio-economic rights litigation. For instance, while affirming its powers to make a structural interdict in the TAC case, the 2001 (1) SA 46 (CC), and TAC case (note 5 above).

762005 (8) BCLR 786 (CC).

77 See D Bilchitz 'Health' in S Woolman, T Roux, J Klaaren, A Stein \& M Chaskalson (eds) Constitutional Law of South Africa (1996) Juta \& Company and Centre for Human Rights, University of Pretoria [2nd Edition, Original Service 2005] pp 56A-i to 56A-47, at p 56A-24. See also M Heywood 'Preventing Mother-to-child HIV Transmission in South Africa: Background, Strategies and Outcomes of the Treatment Action Campaign Case against the Minister of Health' (2003) 19 SAJHR 278, 312; Swart (note 1 above); and Davis (note 2 above).

78 Davis (note 2 above) 6.

79 Bilchitz (note 1 above) 510.

80 See T Roux 'Legitimating Transformation: Political Resource Allocation in the South African Constitutional Court' (2003) 10 Democratization 92; and D Brand 'The Proceduralisation of South African Socio-economic Rights Jurisprudence, or "What are Socio-economic Rights for?" in H Botha, A Van der Walt \& J Van der Walt (eds) Rights and Democracy in a Transformative Constitution (2003) 33, 51. 
Court cautioned that due regard must be paid to the roles of the legislature and the executive in a democracy. ${ }^{81}$

In order to respect the other branches of state, the Court has, even in the face of government recalcitrance, struggled to convince itself that government would comply with its orders in good faith. In the $T A C$ case, for instance, the Court declined to grant the structural interdict because, in its opinion, 'the government has always respected and executed orders of this Court' and there was 'no reason to believe that it will not do so, ${ }^{82}$ This conclusion appears to have been motivated by evidence that emerged during the hearing that the government had 'made substantial additional funds available for the treatment of HIV, including the reduction of mother to child transmission'. However, this evidence blinded the Constitutional Court to the high degree of recalcitrance demonstrated by the State during the hearing of the case, particularly the declaration by the Minister of Health that the government would not respect the judgment of the Court. ${ }^{84}$ Recalcitrance, in addition to the seriousness of the matter in issue, saving innocent babies from a deadly disease, was justification for the issuance of a structural interdict. ${ }^{85}$ This matter was especially serious because of the generally inadequate response of the government in tackling the HIV/AIDS epidemic. As already observed above, the policy of the government in relation to HIV has been notable for its very slow progress in coming to terms with the health crisis facing the country. There had indeed been a tremendous amount of bungling and a high degree of reluctance expressed with regard to providing nevirapine. ${ }^{86}$

At the very least, the Constitutional Court should have retained jurisdiction, without requiring that a report be filed by a stated date. The Court could have left itself open to whichever party wanting to contest the manner in which the order was being implemented. ${ }^{87}$ The mere fact that the Court retained jurisdiction over the case could have propelled the government to act more cautiously because of the knowledge that any deleteriousness would easily be brought to the attention of the Court and might also spark media frenzy.

The Court would have only graduated into more specific and detailed directions, if necessary, on the basis of the evidence brought before it by those who

83 Para 120, the evidence indicated an increment in the HIV treatment budget from R350 million to R1 billion which would increase to R1,8 million the following year.

84 See Bilchitz (note 56 above) 23-24.

85 Geoff Budlender has submitted that one of the indications of whether a structural interdict is appropriate is the risk of severe consequences, such as loss of life, even in the case of good faith failure on the part of government to comply with its obligations. G Budlender 'Justiciability of Socio-economic Rights: Some South African Experiences' in Y Ghai and J Cottrell (eds) Economic, Social and Cultural Rights in Practice The Role of Judges in Implementing Economic, Social and Cultural Rights (2004) 33, 358. See also D Bilchitz 'Placing Basic Needs at the Centre of Socioeconomic Rights Jurisprudence' (2003) 4 ESR Review 2, 4; and Roach \& Budlender (note 7 above) 333.

86 Bilchitz (note 56 above) 23-24.

87 Unlike the declaration in the Grootboom case, this would not have caused any confusion, as the order made in this case was a clear mandatory direction as to what had to be done. 
would have come back to it, and by the attitude of the government. Although this may have exposed the Constitutional Court to protracted litigation, a thing that the Court wanted to avoid, it would have been beneficial in many respects. It would have demonstrated that in cases dealing with serious matters, and where recalcitrance is detected, the Court would engage with a case until its orders are implemented just as it did in the Sibiya case. ${ }^{88}$

The retention of jurisdiction would have further enabled the Court to continue to engage the state as regards the mechanisms of policy implementation. ${ }^{89}$ Indeed, as a matter of fact, it is only through litigation that the courts can engage the other organs of state in litigation on matters of policy implementation and its impact on human rights. Maximising engagement of this nature is justified, amongst others, by the fact that not so many cases have been filed before the Constitutional Court since the Constitution was adopted. It is, therefore, important that the Court should takes full advantage of those cases before it to engage fully with the other organs of state. This can be done effectively only if supervisory jurisdiction is retained in deserving cases. Another opportunity for such engagement may arise only after a considerably long time. It is, for instance, almost eight years since the $T A C$ case was heard. Yet, in spite of the contentions surrounding the government's response to HIV/AIDS, the Court has not had another opportunity to engage the government on this epidemic. In this regard, the $T A C$ case was a very good opportunity for the Court to use the structural interdict in order to elicit an adequate response from the state.

\section{(c) Rand Properties case - a flicker of hope?}

The recent case of Occupiers of 15 Olivia Road and Others $v$ City of Johannesburg and Others (Olivia case) ${ }^{90}$ introduces a new dimension into the discussion of the approach of the Constitutional Court to the structural interdict. This case, which began in the High Court of Johannesburg, was instituted by more than 400 occupiers of two 'bad' buildings in Johannesburg to resist their eviction, which was scheduled to take place in pursuit of the City of Johannesburg's regeneration programme. The programme was intended to revamp the city by, among others, rehabilitating all 'bad' buildings. The High Court had found that the City's programme fell short of the requirement to provide suitable relief for the people in the city who were in a crisis or in desperate need of housing. The Court interdicted the eviction. On appeal to

90 Case CCT 24/07 [2008] ZACC 1. For a discussion of the history of this case see L Chenwi \& S Liebenberg 'The Constitutional Protection of those Facing Eviction from Bad Buildings' (2008) 9(1) ESR Review 12. 
the Supreme Court of Appeal, ${ }^{91}$ the Court found the buildings to be unsafe and authorised the eviction of the occupiers and ordered them to vacate. ${ }^{92}$ The occupiers appealed to the Constitutional Court against their eviction. In the course of hearing the case, the Constitutional Court ordered what would be described as 'an interim structural interdict'. It was directed that the parties 'engage with each other meaningfully ..., in an effort to resolve the differences and difficulties aired in this application'. The parties were also ordered to file affidavits before the Court on or before 3 October 2007 reporting on the results of the engagement between them as at 27 September $2007 .^{93}$ The approach was justified on the basis of the fact that the City has an obligation to engage vulnerable people before making decisions that adversely affect them. The Court held:

The City has constitutional obligations towards the occupants of Johannesburg. It must provide services to communities in a sustainable manner, promote social and economic development, and encourage the involvement of communities and community organisations in matters of local government. It also has the obligation to fulfil the objectives mentioned in the preamble of the Constitution to '[i]mprove the quality of life of all citizens and free the potential of each person' .... In light of these constitutional provisions a municipality that ejects people from their homes without first meaningfully engaging with them acts in a manner that is broadly at odds with the spirit and purpose of the constitutional obligations set out in this paragraph taken together. ${ }^{94}$

In remedial terms, the importance of the approach adopted by the $\mathrm{CC}$ in the case lies in the fact that besides being the precursor of interim relief, the order itself provided interim protection for the applicants against eviction. The engagement process resulted in an agreement on interim measures by which the City agreed to take steps to render the buildings safer and more habitable. This was to be achieved among others by the installation of chemical toilets, the cleaning and sanitation of the buildings, the delivery of refuse bags, and the installation of fire extinguishers. A time frame of 21 days was agreed on within which these things were to be done. ${ }^{95}$ The Court found this agreement to be 'a reasonable response to the engagement process' and commended the City for being more humane. ${ }^{96}$ Furthermore, as is demonstrated below, the approach of the Court in promoting dialogue has the potential of obtaining

91 See City of Johannesburg $v$ Rand Properties (Pty) Ltd and Others (2007) (6) SA 417; 2007 (6) BCLR 643. For a discussion of this case see G Quinot 'An Administrative Law Perspective on "Bad Buildings” Evictions in Johannesburg inner city' (2007) 8(1) ESR Review 25; and C Mbazira, 'An Overview of the Constitutional Court Hearing of the Inner-city Evictions Case' (2007) 8(3) ESR Review 12.

92 The Court, however, ordered the provision of alternative accommodation by relocation to a temporary shelter of those in desperate need of housing.

93 At para 5. The Court found justification for this order in the advantages of attempting to resolve a dispute amicably; and referred to a number of judicial decisions to justify this. These included the Grootboom case and Port Elizabeth v Various Occupiers (Port Elizabeth case) 2005 (1) SA 217 (CC); 2004 (12) BCLR 1268 (CC), at para 39.

96 Ibid para 28. 
meaningful enforcement of the court orders with the least involvement of the court.

Nonetheless, in spite of the seemingly progressive approach in Rand Properties, the Constitutional Court is yet to define the norms and principles governing the structural interdict. The Sibiya case, however, shows that the Court is willing to be guided by some norms and principles on how to exercise supervisory jurisdiction. The principles in this case, however, need to be developed and applied consistently and in a broader manner. This is in addition to the fact that the principles thus far address only one aspect of the structural interdict: the supervision process. There is need for a comprehensive list of norms and principles which address not only the supervision process but also the process of determining when the relief is appropriate. The principles deduced from the Sibiya case could be developed together with those deduced from the approach of the High Courts into a comprehensive set of structural relief norms and principles. This is what the next section sets out to do.

\section{Norms And Principles for the Structural InTERdict}

Roach and Budlender have made an attempt to define some of the principles that could guide the courts in determining when a structural interdict is an appropriate remedy. ${ }^{97}$ They argue that the remedy should be granted where there is evidence to believe that the government may not comply promptly with the court order. The same applies to those cases where the violation arises from 'neglect, inadequate budgets and inadequate training of public officials'; ${ }^{98}$ and where the consequences of 'even a good-faith failure to comply with a court order are so serious that the court should be at pains to ensure effective compliance,. 99 Another circumstance where Roach and Budlender judge a structural interdict to be appropriate is where there is evidence of government's incompetence or lack of capacity to provide for the rights: ' $[t]$ he greater the degree of the government's incompetence or lack of capacity to provide for the rights, the stronger the case for supervisory jurisdiction including requirements that government submit a plan and progress reports for the court's approval'.

While I find Roach and Budlender's article very useful in defining principles guiding the grant of a structural interdict, I find it incomprehensive; indeed, Roach and Budlender do not pretend to be comprehensive in this regard. There is a host of other norms and principles that could guide the courts in using the structural interdict, as discussed below. 


\section{(a) Utilisation as a remedy of last resort in a graduated manner}

Execution by the courts of administrative functions deemed to be the preserve of the executive organ of the state amounts to substitution of executive with judicial discretion. Fletcher contends that such substitution becomes legitimate only when the political bodies are 'seriously and chronically in default'. He contends that as long as those political bodies remain in default, judicial discretion may be a necessary and legitimate substitute for political discretion. ${ }^{101}$ On a similar note, Eisenberg and Yeazell submit that courts usually intervene in institutional cases not so much to take affirmative action in conflict with the other branches of government; in their opinion, such intervention is justified by the need to fill a vacuum which the other branches have created owing to inaction or neglect. ${ }^{102}$

It is clear from the above that government deficiency, especially one of a chronic nature, should be the basis of intervention in what may be considered administrative or policy matters. Greater judicial intrusion is, therefore, warranted only if there is a failure by the other organs. ${ }^{103}$ This notwithstanding, the courts should ascertain in the first place whether there is still any chance of using executive or legislative discretion to eliminate the constitutional violation and to fill the vacuum. If this is still possible, intervention by substitution of discretion will not be justified. The court's initial response should be aimed at persuading the government to exercise its discretion in a manner that eliminates the violation. The government should be given an opportunity to display the plans it intends to follow to eliminate the violation. The court could also require the parties to negotiate a plan and report back to it. It is only when all these attempts fail that the court should intervene by taking administrative decisions.

At this level, the courts could exercise what has been described as 'remedial absentation'. ${ }^{104}$ A court exercising remedial absentation merely retains jurisdiction to stop the infringement while allowing the state to formulate a remedial plan indicating how it intends to end the infringement. At this stage, the court should only order the defendant to produce a plan for judicial evaluation. The order may be accompanied by guidelines suggested by the court. This is important, not only because a defendant making a good faith attempt may need guidance, but also because a recalcitrant defendant will produce an inadequate plan unless closely instructed. ${ }^{105}$ This approach limits judicial involvement in what may be viewed as policy matters. Additionally, it allows the court to harvest the special expertise of the defendant and to secure co-operation in this regard. Remedial absentation should be contrasted with

101 Fletcher (note 24 above) 637.

102 Eisenberg \& Yeazell (note 24 above) 495-496. See also D Horowitz The Courts and Social Policy (1977) 2 and 24, who submits that one reason for judicial involvement in social policy matters has arisen from the reticence of other policymakers. In his opinion, sometimes, although a judicial decision on these issues may be imperfect, it may be the best that is available.

103 Special Project (note 17 above) 823.

104 Ibid 796.

105 Ibid 798 . 
judicially-imposed remedies, which are formulated without the benefit of the expertise or skills of the parties and may be considered to be intrusive. ${ }^{106}$

It should be noted, however, that there could be circumstances where a judicially-imposed remedy is needed. This occurs in those cases where it is necessary to alleviate an intolerable condition immediately, or where the case implicates non-systemic aspects susceptible to immediate relief. Even then, the court may be forced to combine judicial imposition with remedial absentation. The Westville case is an example of this: ${ }^{107}$ the Court ordered that the applicants be provided with ARVs immediately, in addition to the state filing a plan on how it intended to comply with the Court's order. Immediate relief was provided to the applicants, and a long-term remedy was sought for similarly-situated people. This made it possible for benefits to be provided to the applicants even when an appeal had been lodged. The Olivia case tells the same story.

\section{(b) Participation}

Whatever the form taken by structural litigation, the court must strive to ensure that it brings on board the widest array of stakeholders. This applies especially to those persons who may be affected by any relief ordered in the case. Participation of a wide array of stakeholders has many advantages, especially as regards the implementation of the remedy and attendance to polycentric interests implicated by the case. Abram Chayes has submitted that:

Public law litigation, because of its widespread impact, seems to call for adequate representation in the proceedings of the range of interests that will be affected by them. At the stage of relief in particular, if the decree is to be quasi-negotiated and party participation is to be relied upon to ensure its viability, representation at the bargaining table assumes very great importance, not only from the point of view of the affected interests but from that of the system itself. $^{108}$

The participation should focus on individuals, groups or organisations whose interest may be affected by the case. ${ }^{109}$ In the context of government as the defendant, it may be necessary to ascertain the interests of other spheres or departments of government. In semi-federal South Africa, as defined by the Constitution, ${ }^{110}$ national, provincial and local government interests may be invoked in the case. The case may also implicate constitutional competences of these spheres of government as regards the provision of social goods and 
services. ${ }^{111}$ Ignoring these interests and competences may affect the efficacy of the remedy obtained and may lead to imposition of remedial burdens which fall outside a government sphere's constitutional mandates. Involvement of a wide range of stakeholders is also necessary in securing collaboration between the different spheres or departments of government and the different stakeholders in the remedial process. It is also important to note that government programmes often consist of partially co-ordinated outputs of a number of departments and organs of state. In addition to the state actors, there could also be non-state actors such as trade unions and organised groups which influence the direction of the government programme. ${ }^{112}$ It is prudent that these actors be consulted if necessary and practicable.

Sturm has suggested that the forms of interaction used in the decisionmaking process should promote involvement, co-operation and consensus. He suggests further that the process should also mitigate the unequal power, resources, and sophistication of participants. ${ }^{113}$ This is important because it establishes equality of participation in the process and encourages parties to bring their interests to the fore without fear. It is particularly important with regard to socio-economic rights because of the imbalance of power which usually exists between poor and marginalised communities and powerful government or other artificial entities.

It is also vital that institutional reform includes identification of the various groups and entities whose co-operation is necessary. This is in addition to ascertainment of the needs and interests of those groups and entities, and assessment of the likely impact of any proposed reforms on their interests. ${ }^{114}$ The involvement of a wide variety of participants increases the number of alternative remedial proposals before the court. ${ }^{115}$ Participation will also allow all the stakeholders to be educated on the nature of the case, the remedial plan, and its likely impact. If crucial stakeholders misunderstand the remedy, implementation may be grounded simply because they do not know both what to do and the objectives to be realised: ${ }^{116}$

When those excluded complain, often justifiably, that their position has not received a fair hearing, political as well as bureaucratic obstacles to implementation are often created. Thus, in order to minimise opposition to implementation, it is advisable to invite the participation at the decree formulation stage of relevant non-parties ... Participation by such non-parties may have another advantage: they may raise policy and implementation factors overlooked by the plaintiffs and defendant administrators yet pertinent to the shaping of the decree. The court can employ various procedural devices to promote this expanded participation, such

111 See Schedules 4 and 5 of the Constitution for the competences of the different spheres of government. See also C Mbazira Realising Socio-economic Rights in the South African Constitution The Obligations of Local Government. A Guide for Municipalities (2006); J De Visser 'A Perspective on Local Government's Role in Realising the Right to Housing and the Answer of the Grootboom Judgment' 8 (2004) 2 Law, Democracy \& Development 201; and J De Visser 'Powers of Local Government' (2002) 17 SA Public Law 223.

112 Note (note 21 above) 433.

113 Sturm (note 10 above) 1410.

114 Note (note 21 above) 433.

115 Special Project (note 17 above) 804 .

116 Note (note 21 above) 440. 
as inviting groups whose interests may be affected by the decree to file amicus briefs or, if necessary, to intervene at the remedial stage. ${ }^{117}$

However, the remedial process should not be diluted by participation to the extent that effective remediation and reasoned decision making are lost. As discussed below, ${ }^{118}$ reasoned decision making is another norm that has to be realised by structural litigation. ${ }^{119}$ The same could be said in regard to effective remediation. The consensual remedial model, as discussed above, ${ }^{120}$ appears to be the most suitable for realising the norm of participation. This model may, however, sacrifice reasoned decision making and effective remediation. Nonetheless, this depends on how the process is conducted and the oversight role played by the court. The court could direct the parties on agreements which are based on reason, and may reject those which do not realise effective remediation. Participation should also not be allowed to slow down the remedial process unnecessarily. ${ }^{121}$

\section{(c) Impartiality and judicial independence}

Impartiality and judicial independence is a norm to be preserved in all forms of judicial processes. The need for impartiality accords legitimacy to the judicial process and plays a very important role in producing remedies which are acceptable not only to the parties but to the public at large. It should be noted, however, that the need for impartiality and independence in structural litigation is not only relevant but also complex. This is because of the active role played by the judge, not only in formulating the remedy but also in its implementation. Impartiality and judicial independence are also heightened by the administrative nature of the tasks that the judge has to discharge and his or her continued involvement in the reformation process. This is because such participation may threaten the judge's independence and impartiality. Fiss has thus warned that, to some extent, this threat is tied to a peculiar characteristic of the structural remedy, as it places the judge in an architectural relationship with the newly reconstituted state bureaucracy. Fiss submits that a judge is likely to identify with the organisation he or she is reconstructing, and that such identification is strengthened with each cycle of remediation. ${ }^{122}$

Fiss's statement should nevertheless be qualified. It is true only in those cases where the same judge has been involved with an institution for a considerably long time and has discharged functions that place him or her in an adminstrative position in that institution. Yet, the judge could still use his or her judicial training to distance him- or herself from the institution. This may not, however, be easy; the judge must strive to ensure that his or her decisions are fair, unbiased and supported by facts that are related to the legal problem 
in issue. ${ }^{123}$ Judicial independence would also allow the judge to make judicial orders, without interference, on the basis of legal standards and norms. It therefore remains the duty of the judge not only to assert his independence, but also to avoid being unnecessarily involved in tasks that would undermine this independence. Where a political organ can make remedial decisions, this should be considered a measure of first resort, and judicial usurpation of the process a matter of last resort. This is not to ignore the fact that in some cases it may be plainly clear that the political processes have failed and that court assumption of the task is the only reasonable thing to do. Even then, the political process should be given a second chance, although under the supervision of the court. ${ }^{124}$

Fiss contends that the expert is used as an intermediate structure whicht stands between the judge and the institution, on the one hand, and on the other hand, between the judge and the body politic. ${ }^{125}$ Nevertheless, it is not necessary for the court to give itself a posture of complete disinterest, considering the fact that the court is the bearer of the ultimate obligation to devise an effective remedy. In South Africa, the courts need not exhibit complete disinterest; this is because they are expressly mandated to review the constitution and guarantee appropriate relief. ${ }^{126}$ Even when a court delegates the obligation to an expert, the expert is, to all intents and purposes, deemed to be a representative of the court. The court must ensure that the remedy, whether devised by the expert or by the court itself, enforces the substantive legal norms. And also, as seen above, ${ }^{127}$ the expert model inherently exposes the expert to perceptions of partiality on his or her part, especially where participation is not guaranteed to its fullest. According to Nagel, the experts 'are not judges and therefore neither their training nor role necessarily assures the habits and capacities required for the kind of disciplined impartiality we expect of judges.' ${ }^{12}$

Nagel contends further that judges cannot be counted on to correct any bias in the formulation of the decree because the facts in the expert's report are traditionally alterable only' if clearly erroneous. ${ }^{129}$ It is my considered view, however, that the possibility of bias can be overcome if the judge keeps a close eye on the expert and requires periodic updates. The courts should also take care not to appoint experts who are close to the interests of one of the parties. In some cases, it may serve the interests of justice if more than one expert is appointed; a panel of experts as opposed to an individual expert is less likely to be biased. But this does not mean that all cases merit the appointment of a

123 Sturm (note 10 above) 1410.

124 See discussion of the norm of utilisation as a remedy of last resort in a graduated manner at section IV(a) above.

125 O Fiss The Civil Rights Injunction (1978) 56.

126 See sections 38 and 172 of the Constitution of South Africa, 1996.

127 At section II(a).

128 R Nagel 'Controlling the Structural Injunction' (1984) 7 Harvard Journal of Law and Public Policy 395,403 to 404 .

129 Ibid 404 
panel. The magnitude of the task to be accomplished should also be a factor to consider in deciding whether or not a panel as opposed to an individual expert should be appointed.

\section{(d) Reasoned decision making}

One of the criticisms levelled against structural litigation is that it relegates reasoned decision making to the background and exalts remedies reached through negotiation. ${ }^{130}$ There is, therefore, a need for structural remedies to be based on reasoned decision making. Structural litigation should be conducted with open awareness of the fact that the litigation implicates interests beyond those of the parties. The court should determine whether the case negatively impacts on interests other than those of the parties. In addition to this, the court should support its decisions with legal norms and standards in the form of normative standards established, for instance, in the Bill of Rights. This is where reasoned decision making becomes relevant, as reflected in the way the judge interprets and applies the normative standards in issue.

The judge has to justify his or her decision as based on the law. This helps to forestall accusations that the judge has applied his or her own value judgement to decide the case. Reasoned decision making in structural litigation terms therefore gives legitimacy to judicial intervention as being based on legal norms and the need to solve systemic problems. When remedies are based on reasoned decision making, they accord legitimacy to the process, which translates into acceptance of the directions issued by the court.

The expert remedial formulation model $^{131}$ is more capable of realising reasoned decision making in comparison with the bargaining and legislative hearing models. Usually, the court-appointed experts come with technical expertise and a capacity to gather and assess large quantities of information. In spite of this, whether a case requires an expert model of remediation should depend on the circumstances of the case. If a case has many technical aspects which need to be assessed before an effective remedy is crafted, it will definitely need expert help. But if a case merely requires ascertainment of some factual aspects, the hearing model and not the expert model may be the most appropriate. Reasoned decision making should, therefore, not be exalted blindly by appointing an expert without first considering the circumstances of the case.

Finally, it should be noted that reasoned decision making also promotes the principle that aims at ensuring that remediation complies with the substantive norm, as discussed in the next subsection. The substantive norm is the law which protects the right(s) in issue.

130 O Fiss 'Against Settlement' (1984) 93 Yale LJ 1073, 1083. See also Horowitz (note 102 above) 22.

131 See section II(a) above. 


\section{(e) Remedy that complies with substantive norms}

The reason people litigate is to enforce their rights. The remedies must, therefore, as much as possible, be intended to realise the rights. It should not be denied, though, that in certain cases, the interests of justice might require that the remedy granted should be one that most appropriately attends to the demands of the case. This is even when the remedy selected is incapable of realising the right in full. This does not, however, mean that the court should completely abandon the need to develop the substantive rights as protected.

It is advisable that the court begins by detailing the normative standards implicated by the right. In the context of socio-economic rights, this approach would help to give content to the rights. This is important because of the fact that the Constitutional Court is yet to give substantive content to the socioeconomic rights in the Constitution. ${ }^{132}$ Giving substantive content to the rights helps the court and the parties to understand what they are working towards. ${ }^{133}$ The remedies will be structured with these objectives in mind. The normative content also provides a basis upon which the efficacy of the remedies selected can be criticised and evaluated. In addition, the Court will use these normative standards to ensure that its model of supervision is the most effective in terms of realising the objectives of the substantive norms.

\section{(f) Flexibility, monitoring and supervision}

In litigation challenging systemic violations, the court may embark on a search for the most appropriate remedy without full knowledge of the requisite facts, interests and obstacles relevant in this regard. The necessarily speculative nature of this enterprise therefore means that no single order can be regarded as final. Additionally, implementation of the remedy may continue for a long time. ${ }^{134}$ According to Fiss, the remedy 'must always be open to revision, even without the strong showing traditionally required for modification of a decree, namely, that the first choice is causing grievous hardship. A revision is justified if the remedy is not working effectively or is unnecessarily burdensome'. ${ }^{\text {, }}$

It is therefore important that the court should proceed with flexibility and craft its decree in a manner that allows easy adjustment, should the need to do so arise. ${ }^{136}$ The need to revise the decree is made inevitable because of the detailed nature of structural decrees, and sometimes because of the lack of

132 Bilchitz (note 56 above).

133 K Iles 'Limiting Socio-Economic Rights: Beyond the Internal Limitation Clauses' (2004) 20 SAJHR 448, 454. See also Pieterse (note 55 above) 410; and Davis (note 2 above) 304-5.

134 Special Project (note 17 above) 789.

135 Fiss (note 122 above) 49. Fiss also notes that it is this which explains the fact that specificity usually comes at a late stage of the remedial process. The judge will begin with very broad remediation and gradually move to specifics.

136 See Doucet-Boudreau case (note 72 above) para 68. In the TAC case (note 5 above), the Constitutional Court observed that a factor that needs to be kept in mind is that policy is and should be flexible and that court orders concerning policy choices made by the executive should not be formulated in ways that preclude the executive from making such legitimate choices (at para 114). 
judicial expertise in drafting some of them, since some of the experts who draft these decrees may not have a judicial background. ${ }^{137}$

The court may also have to monitor closely the implementation of its order and obtain information that may be needed to make adjustments in the remedial standards should the need to do so arise. ${ }^{138}$ This can be achieved only if the court retains jurisdiction and assumes an active oversight role. ${ }^{139}$ The court should nevertheless be careful not to interfere with the implementation process if it is not necessary to do so. Although the parties should be relied on for information and the need for adjustments, the court should be careful not to be distracted by parties who may be interested in protecting their interests at the expense of other equally important interests. Plaintiffs may underplay the degree of compliance, while defendants may exaggerate it. All this may distract the remedial process.

The need to adjust the court order may also arise, for instance, when it transpires during the implementation period that the defendant cannot successfully implement the decree without the co-operation of persons or departments not party to the original suit. ${ }^{140}$ Other participants whose co-operation is needed may, for instance, include different spheres of government. In such an event, notice should be served on the third party participants, with a view to determining whether they are opposed to the order, and the likely impact that it may have on their activities. In other cases it may merely be necessary to widen the geographical scope of the order. Some adjustments of the order may be motivated by changed legal standards, especially following decisions of higher courts or even legislative enactments.

\section{CONCLUSION}

The South African courts have not comprehensively defined norms and principles that could be used to determine the appropriateness of the structural interdict. In this paper, I have illustrated some of these norms and principles. I would nonetheless not pretend that the norms and principles I propose here are exhaustive. I have provided a foundation on which one may build additional norms and principles.

It is important that the courts should only intervene by way of a structural interdict where the other branches are 'seriously and chronically in default' as regards the exercise of their discretion. ${ }^{141}$ Even then, intervention should be graduated, ${ }^{142}$ choosing first to merely retain jurisdiction and allow the state to tackle the constitutional violation. This could be followed by a requirement

137 Most structural decrees arise from negotiated settlements and the court may not be able to anticipate the impact of every aspect of the decree. It is, therefore, fair that the judge oversees implementation of the decree to be able to make adjustments should the need to do so arise.

138 Note (note 21 above) 440.

139 See Special Project (note 17 above) 817.

140 Ibid 818.

141 Fletcher (note 24 above) 637. See also Eisenberg \& Yeazell (note 24 above) 495-496.

142 See Fiss (note 122 above) 35-36; and K Cooper-Stephenson 'Principle and Pragmatism in the Law of Remedies' in J Berryman (ed) Remedies, Issues and Perspectives (1991) 1, 36. 
to submit a report to the court and to the opposite party detailing the plan to eradicate the violation. Where necessary, the court may more intrusively devise the plan and supervise its implementation. It has been cautioned, however, that there could be cases which are of such a very serious nature that a high degree of intervention is immediately necessary. ${ }^{143}$

In all these processes, the court should ensure that all persons whose interests may be affected by the litigation process participate in the remedial formulation process to the extent that this is necessary and practicable. ${ }^{144}$ The courts could use various models of the structural interdict, including the expert model and the legislative hearing model, to realise this. The remedy should be flexible, and the court should be prepared, if need be, to adjust it at any time..$^{145}$ The adjustments also allow the judge to find what is considered to be the most appropriate means of responding to the constitutional violation. This is because, usually, the structural interdict may begin as experimentation of several remedies, and perfection may only come after a number of adjustments. $^{146}$

Sometimes the main issue is not when a violation is going to be uprooted. Rather the issue is what steps are being undertaken to begin the uprooting process. In such a context, it is the direction and rate of change that may be important and not the final outcomes, as these may still be too far away. ${ }^{147}$ Reform may be slow and almost viewed as amounting to failure, but this may be necessary to accommodate the unforeseen obstacles. A slow but steady process of uprooting the violation is far better than short-term artificial measures which may not overcome all the obstacles ahead. Artificial or 'quick fix' measures, although dramatic, may stall or dissipate in the long run.

It is important that the court take its time to study all the obstacles so that it is able to fashion long-term solutions to them. It is because of this that the US Supreme Court in the Brown case, ${ }^{148}$ for instance, initially merely ordered that the state act with all deliberate speed and advised the local courts to act with flexibility in their remedial exercise. This provided both the state and the courts with time to study the obstacles and to find solutions to them. It also illustrates the concern of a court to provide space for public authorities to implement a far-reaching and contentious order gradually. ${ }^{149}$

143 The Westville case (note 3 above) has been given as an example. In spite of this, one sees that the graduated response is still applied to a certain extent.

144 See Chayes (note 13 above) 1310; and Sturm (note 10 above) 1410.

145 See Doucet-Boudreu case (note 72 above) para 68.

146 See Fiss (note 122 above) 49.

147 E Frug 'The judicial power of the purse' (1978) 126 Univ of Pennsylvania LR 715, 790.

148 Note 14 above.

149 Davis (note 2 above) 322. Davis has likened this approach to the reasonableness review approach in Grootboom and TAC cases, which appear to accord deference to the executive. However, the distinction, he submits, is that the South African socio-economic rights cases were not as controversial as the Brown case. 